\title{
Resúmenes Tesis: Doctorado en Educación en Ciencias Experimentales
}

\section{Contribución de las tecnologías de la información y la comunicación (TIC) a la enseñanza y los aprendizajes de las Ciencias Morfológicas}

\author{
Ana Patricia Fabro \\ anapfabro@hotmail.com \\ Directora: Dra. Graciela Curi. \\ Co-directora: Mg. Alicia Costamagna. \\ Lugar de realización: Cátedra de Morfología \\ Normal. Facultad de Bioquímica y Ciencias \\ Biológicas. \\ Universidad Nacional del Litoral.
}

Fecha de la defensa: 5 de noviembre de 2015.

\section{Resumen}

Los aportes de la sociedad del conocimiento y la incorporación de las tecnologías en el aula, han modificado sustancialmente los procesos de enseñanza y aprendizaje.

El estudio de las Ciencias Morfológicas (que comprende las disciplinas Anatomía e Histología) no puede estar ajeno a esta situación. Conociendo que los alumnos necesitan diferentes tiempos para procesar la información obtenida, característica neurobiológica esencial para el desarrollo de aprendizajes significativos, es necesario proponer la implementación de estrategias que favorezcan el trabajo de observación macro y microscópica de imágenes y modelos anatómicos e histológicos, durante un tiempo más prolongado, y en diferentes ámbitos.

Para contribuir a ello se implementa en el año 2008 en la Cátedra de Morfología Normal de la Facultad de Bioquímica y Ciencias Biológicas de la Universidad Nacional del Litoral, en la asignatura Anatomía e Histología, de la carrera de Licenciatura en Nutrición, una propuesta de enseñanza de modalidad combinada (blended learning o b-learning), de forma tal que el cursado de la mencionada asignatura, (desarrollado mediante clases de coloquios, talleres y trabajos prácticos presenciales) se complementa con una propuesta con alto contenido visual, presentada en el entorno virtual de la FBCB.UNL.

Para investigar de qué manera la propuesta contribuye a los procesos de enseñanza y aprendizaje de las Ciencias Morfológicas se diseñó una investigación, que valora a través de una metodología cualicuantitativa, los aportes que la misma realiza a los procesos de enseñanza y aprendizaje, durante el cursado de la asignatura en el segundo cuatrimestre del año 2013.

A partir de lo investigado se aprecia que la propuesta se desarrolla en un ámbito que cuenta con una infraestructura adecuada en cantidad y calidad para la implementación de innovaciones mediadas por TIC. Asimismo la utilización de las TIC para la enseñanza y los aprendizajes de las Ciencias Morfológicas logra una producción y gestión más significativa del conocimiento y el desarrollo de dominios procedimentales y de comprensión en docentes y alumnos.

\section{Summary}

Contribution of Information and Communications Technology (ICT) to teaching and 
learning of Morphological Sciences

The contributions of the knowledge society and the incorporation of technologies in the classroom, have substantially altered the teaching and learning processes.

The study of morphological sciences (comprising the Anatomy and Histology disciplines) can not be outside to this situation. Knowing that students need different times to process the information obtained, essential neurobiological characteristic for the development of significant learning, is necessary to propose implementing strategies to promote the work of macro and microscopic observation of anatomical and histological images and patterns, for a while longer, and in different environments.

To support this is implemented in 2008 at the Department of Morphology Normal of Biochemistry and Biological Sciences Faculty, of the Universidad Nacional del Litoral, in the course Anatomy and Histology of the Bachelor in Nutrition, a proposal for teaching combined modality (blended lear- ning or b-learning), so that the completed of said subject, (developed by classes of seminars, workshops and classroom practical work) is complemented by a proposal with high visual content, in the virtual environment of FBCB. UNL.

To investigate how the proposal contributes to the teaching and learning of morphological sciences was design a research, which values through a qualitative and quantitative methodology, contributions that it makes to the teaching and learning processes, during development of the course in the second quarter of 2013.

From the investigation it shows that the proposal is developed in an environment that has adequate infrastructure in quantity and quality to implement innovations mediated by ICT. Also the use of ICT for teaching and learning of Morphological Sciences achieves a more significant production and management of knowledge, and the development of procedural and understanding domains in teachers and students.

\section{Actitudes hacia la química de estudiantes de carreras biológicas (Licenciatura en Biodiversidad y Profesorado en Biología) de la Universidad Nacional del Litoral y su influencia en el aprendizaje y rendimiento académico}

\section{María Silvina Reyes}

mariasilvinareyes@hotmail.com

Director: Dra. Silvia Porro / Co-Director: Mg. María Elida Pirovani

Lugar de realización: Cátedra de Química General e Inorgánica. Departamento de Ciencias Naturales. Facultad de Humanidades y Ciencias. Universidad Nacional del Litoral Fecha de la defensa: 25 de Junio de 2015

\section{Resumen}

Los objetivos de la presente tesis fueron: evaluar la actitud frente a la química de alumnos de las carreras de Licenciatura en Biodiversidad (LB) y Profesorado (PB) utilizando instrumentos cuantitativos (cuestionarios según el método del Diferencial Semántico y según la escala Likert) y cualitativos (observaciones de clases y entrevis- 
tas en profundidad); analizar la evolución o cambio de dichas actitudes durante el transcurso de la carrera; determinar si los métodos de diferencial semántico y escala Likert son equiparables en la medición de actitudes hacia la química; analizar la incidencia de las actitudes hacia la química en el rendimiento académico de los alumnos de las carreras de LB y/o PB y, finalmente, planificar estrategias didácticas a desarrollarse en el futuro que permitan lograr un aprendizaje significativo. Para determinar si las técnicas Likert y Diferencial Semántico pueden medir en forma equiparable la actitud hacia la química se realizó un análisis de concordancia utilizando el índice de Kappa (K). El valor del coeficiente $K$ obtenido en el presente trabajo fue 0,091 lo cual indica que la concordancia entre los instrumentos es insignificante. Este resultado muestra que los instrumentos no detectan de igual modo las mismas actitudes hacia la química y por lo tanto no son equiparables como para que un método sustituya al otro. Es por esto, y respaldados por numerosas investigaciones nacionales e internacionales, que se optó por la técnica Likert para conocer las actitudes hacia la química tanto de los estudiantes de la cohorte 2013 como de alumnos que cursaban las carreras de LB y/o PB en tres momentos diferentes: al inicio ( $1^{\circ}$ año), durante ( $3^{\circ}$ año) y al final ( $5^{\circ}$ año) de las carreras antes mencionadas. En el primero de los casos, se encuestaron a 40 alumnos en QGl y a 30 alumnos tanto en QO como en QB. Los resultados obtenidos indican que existen diferencias estadísticamente significativas $(p \leq 0,05)$ entre las actitudes hacia la química presentadas por alumnos que cursaron QO y QB con respecto a los que cursaban $\mathrm{QGI}$, registrándose una evolución actitudinal positiva mostrada hacia esta disciplina conforme van cursando diferentes asignaturas relacionadas con la química. Para el segundo de los casos se encuestó a la totalidad de alumnos que cursaban cada uno de los años analizados $\left(1^{\circ}, 3^{\circ} \mathrm{y}\right.$ $5^{\circ}$ año), aplicando el cuestionario a 45, 30 y 20 alumnos respectivamente. Se encontraron diferencias estadísticamente significativas $(p \leq 0,05)$ entre las actitudes hacia la química presentadas por alumnos de $3^{\circ}$ y $5^{\circ}$ con respecto a los de $1^{\circ}$ año, registrándose al igual que en la cohorte 2013, una evolución actitudinal favorable mostrada hacia esta disciplina conforme avanza la preparación profesional de los mismos. Con respecto al análisis del rendimiento académico de los alumnos de la cohorte 2013, se concluye que existe una fuerte relación entre las variables implicadas (rendimiento y actitud hacia la química), lo cual queda demostrado por un valor del coeficiente de Pearson mayor a 0,80 en cada uno de los cursos estudiados: QGI, QO y QB.

Las entrevistas en profundidad realizadas a 15 alumnos de la cohorte 2013, posibilitaron conocer aspectos personales de los mismos y permiten concluir que los estudiantes presentan mayor afinidad y encuentran más accesibles los contenidos estudiados en QO comparados con los de QGI. A partir de las observaciones de clases se pudo identificar los estilos de aprendizajes de los alumnos de la cohorte 2013. Se realizaron observaciones de clases en los tres cursos estudiados (QGI, QO y QB). Teniendo en cuenta los tópicos observables se describieron diferentes estilos de aprendizajes: superficial/profundo; participativo/no participativo; dependiente/independiente y competitivo/colaborativo relacionados a cuatro categorías de análisis (contenidos teóricos, trabajo en el laborato- 
rio, relación con el profesor y con los pares). A medida que los alumnos iban cursando las diferentes asignaturas relacionadas con la química estos estilos se fueron modificando pasando, en la mayoría de los casos, de superficial a profundo, de no participativo a participativo y de dependiente a independiente, no modificándose en la categoría relación con los pares, donde en las tres asignaturas se mostraron colaborativos. Por lo anterior, se puede afirmar que los alumnos son capaces de resignificar los contenidos impactando sobre sus estilos de aprendizaje, mostrando avances interesantes en sus trayectorias estudiantiles.

La convergencia de miradas resultado de la aplicación de técnicas integradoras tanto cuantitativas como cualitativas, según lo indicado en la teoría de la triangulación, permite concluir que a medida que los alumnos avanzan y profundizan su vínculo con la química, sus actitudes evolucionan favorablemente, al mismo tiempo que pueden prescindir de las ayudas externas o "andamiajes" del profesor, que sí son requeridos en los niveles introductorios a la disciplina.

\section{Summary}

Attitudes towards chemistry of students of biological careers (Bachelor in Biodiversity and Degree in Biology Teaching) of the Universidad Nacional del Litoral and its influence on learning and academic yield.

The aims of this thesis were to assess attitudes toward chemistry of students of Bachelor in Biodiversity and Degree in Biology Teaching using instruments quantitative (semantic differential and the Likert scale) and qualitative (observations and interviews); analyze the changes in these attitudes during the career; determine whether the methods of semantic differential and Likert scale are comparable and analyze the impact of attitudes toward chemistry in the academic yield. These attitudes were studied in 40 students at General and Inorganic Chemistry (GIC) and 30 studies at Organic Chemistry (OC) and Biological Chemistry (BC) -cohort 2013- and during three stages: at the beginning (1st year), during (3rd year) and at the end (5th year) of their careers. All the students who attended each of the analyzed years (45, 30 and 20 students respectively). Students who were enrolled GIC presented attitudes toward chemistry valued as indifferent and / or negative. When the student advance in their careers, attitudes evolved favorably to take $\mathrm{OC}$ and $\mathrm{BC}$. This behavior was also ratified conducting interviews. This positive attitudinal change was also observed in the students of 3rd and 5th compared to the 1st year a favorable attitude towards this discipline in correlation to the professional preparation, was recorded. The coefficient Kappa obtained in this study was 0.091 , indicating that the correlation between the quantitative instruments is practically null. Regarding the analysis of the academic yield, it concluded that there is a strong relationship between the variables involved (yield and attitude towards chemistry) which is demonstrated with Pearson coefficients greater than 0.80 . 